\title{
PENGEMBANGAN AGROWISATA \\ UNTUK KEMANDIRIAN EKONOMI DAN PELESTARIAN BUDAYA DI DESA KERTA, PAYANGAN GIANYAR
}

\author{
I Made Gunawan \\ Prodi Magister Kajian Pariwisata Universitas Udayana \\ Email: kerthagunawan1771@gmail.com
}

\begin{abstract}
Kerta Village, Payangan, Gianyar regency, Bali, has a large and diverse potential to develop as agrotourism. However, these natural and cultural potentials have not been optimally managed. This study aims to determine the potential of villages that can be developed as agrotourism products, knowing the internal and external factors that influence of agrotourism development, formulating strategy and program to develop it. This study uses qualitative methods, data collection is done through observation, questionnaires, and in-depth interviews on elements of the society, the government and tourism entrepreneurs. Qualitative descriptive analysis was performed by applying the theory of tourism area life cycle, systems theory, and planning theory. The results showed that the village potential that has been depeloping and it can be developed further as agrotourism products, grouped into four categories, namely of nature potential, agriculture, cultural, and attractions. From the view of tourism are life cycle, Kerta Village Agrotourism are in the involvement phase marked by the growing involment of community to tourism activities.
\end{abstract}

Key words: agrotourism, Kerta Village Gianyar, tourism area life cycle, community involvement

\section{Pendahuluan}

Dalam rangka mempercepat dan menata pembangunan wilayah, Pemerintah Kabupaten Gianyar, membagi wilayah ke dalam zona-zona pengembangan dan menetapkan arah kebijakan pembangunan yang dituangkan ke dalam Peraturan Daerah (Perda) Kabupaten Gianyar Nomor 16 Tahun 2012 tentang Rencana Tata Ruang Wilayah (RTRW), khususnya pada bagian ketiga tentang strategi penataan ruang wilayah kabupaten pasal 8 yaitu pengembangan wilayah berdasarkan potensi dan karakter wilayah sebagaimana dimaksud dalam pasal 7 huruf a diwujudkan dengan strategi mengarahkan wilayah Gianyar bagian utara sebagai kawasan pengembangan pertanian dan konservasi daerah resapan air serta culture heritage. 
Di Desa Kerta perkembangan kepariwisataan dalam tiga tahun terakhir menunjukkan adanya peningkatan jumlah kunjungan yang cukup signifikan. Hal ini dapat dilihat dari data kunjungan wisatawan pada dua usaha wisata, yaitu usaha wisata bunga potong tropika "Sekar Bumi" dan usaha wisata petualangan alam "Bali Quad Discovery Tour”. Pada tahun 2012, jumlah kunjungan wisatawan tercatat sebanyak 2.717 orang, tahun 2013 tercatat sebanyak 3.590 orang, dan tahun 2014 meningkat menjadi 6.390 orang atau naik sebesar 77,99\%.

Artikel ini membahas potensi yang sudah dan dapat dikembangkan sebagai produk/daya tarik agrowisata, faktor internal-eksternal yang mempengaruhi pengembangan agrowisata dan strategi pengembangan agrowisata di Desa Kerta Kecamatan Payangan Kabupaten Gianyar. Agrowisata adalah aktivitas wisata yang lebih mengedepankan prinsip-prinsip pemberdayaan, keadilan dan pelestarian. Secara khusus, artikel ini akan merumuskan strategi dan program pengembangan agrowisata di Desa Kerta Kecamatan Payangan Kabupaten Gianyar.

Berdasarkan latar belakang di atas, maka dalam artikel ini dapat ditetapkan tiga rumusan masalah. Pertama, apakah potensi desa yang sudah dan dapat dikembangkan sebagai produk/daya tarik agrowisata di Desa Kerta. Kedua, apakah faktor internal dan eksternal yang mempengaruhi pengembangan agrowisata di Desa Kerta. Ketiga, bagaimanakah strategi dan program pengembangan agrowisata di Desa Kerta.

\section{Konsep, Teori dan Metode}

Penelitian ini menggunakan tiga konsep, yaitu, agrowisata, kemandirian ekonomi, kelestarian alam dan budaya. Landasan teori yang digunakan ada tiga, yaitu teori siklus hidup destinasi wisata (destination lifec ycle), teori sistem, dan teori perencanaan. Penelitian ini memiliki ruang lingkup yang dibatasi dengan tiga variabel, yaitu potensi desa, variabel internal dan variabel eksternal. Hal ini dimaksudkan untuk mengidentifikasi komponenkomponen pariwisata yang terdapat di lokasi penelitian, antara lain atraksi (attraction), fasilitas (amenities), kelembagaan (ancillary), aksesibilitas (accessibility), serta keterlibatan masyarakat dalam pengembangan agrowisata.

Data yang digunakan dalam penelitian ini adalah data kualitatif dan kuantitatif. Data kuantitatif diperoleh dari obervasi, penyebaran kuesioner, wawancara mendalam dan dokumen-dokumen yang berkaitan dengan masalah yang diteliti berupa angka-angka. Sumber data primer dalam penelitian ini terdiri dari 20 responden dari unsur masyarakat, 10 responden dari unsur pemerintah, dan 14 responden dari unsur pelaku/pengusaha pariwisata. Selain itu, sumber data primer, juga terdiri dari 11 informan dari unsur masyarakat, delapan informan dari unsur pemerintah, dan delapan 
informan dari unsur pelaku/pengusaha pariwisata serta para pakar atau orang yang memiliki kompetensi atau mengetahui tentang masalah yang diteliti. Sumber data sekunder terdiri dari dokumen, literatur, buku, hasilhasil penelitian sebelumnya, jurnal, makalah, majalah, surat kabar, gambargambar, dan tulisan-tulisan lainnya yang terkait dengan penelitian ini.

Penyebaran kuesioner dilakukan kepada 20 responden dari unsur masyarakat, 10 responden dari unsur pemerintah, dan 14 dari unsur pelaku/ pengusaha pariwisata. Wawancara mendalam dilakukan kepada 11 informan dari unsur masyarakat, delapan informan dari unsur pemerintah, dan delapan informan dari unsur pelaku/pengusaha pariwisata. Analisis data dilakukan dengan menggunakan matrik Internal Eksternal dan analisis SWOT (Strengths Weaknesses Opportunities Threats). Hasil analisis data disajikan dengan dua cara formal dan informal.

\section{Agrowisata}

Agrowisata merupakan salah satu produk wisata yang memanfaatkan usaha agro sebagai objek wisata. Surat Keputusan bersama Menteri Pariwisata, Pos dan Telekomunikasi, dan Menteri Pertanian No. KM.47/ PW.DOW/MPPT-89 dan Nomor 204/KPTS/HK/0504/1989, agrowisata didefinisikan sebagai suatu bentuk kegiatan yang memanfaatkan usaha agro mulai dari awal sampai dengan produk pertanian dalam berbagai sistem, skala dan bentuk sebagai objek wisata dengan tujuan untuk memperluas pengetahuan, pengalaman rekreasi dan hubungan usaha di bidang pertanian. Goodwin (1998) menyatakan agrowisata sebagai suatu kegiatan yang secara sadar ingin menempatkan sektor primer (pertanian) dikawasan sektor tersier (pariwisata), agar perkembangan sektor primer dapat lebih dipercepat, dan petani memperoleh peningkatan pendapatan dari pariwisata yang memanfaatkan kegiatan sektor pertanian tersebut. Agrowisata dikatakan sebagai kegiatan yang memihak pada masyarakat miskin.

Agrowisata tidak hanya memanfaatkan keindahan alam dan keanekaragaman kegiatan pertanian, tetapi banyak tercipta model-model agrowisata yang memanfaatkan objek-objek pertanian tertentu, seperti agrowisata hortikultura, agrowisata tanaman perkebunan, ataupun varian kebun-kebun perkebunan adalah contoh dari sekian banyak agrowisata yang dapat dikembangkan (Departemen Pertanian RI, 2009).

Kecenderungan masyarakat modern dalam memenuhi kebutuhan hidup melakukan kegiatan mengunjungi dan menikmati obyek-obyek yang mempunyai kekhususan seperti keindahan alam, udara segar, tradisi yang unik, produk olahan tradisional, produk pertanian segar menunjukkan kemajuanyang sangat pesat(Departemen Pertanian RI 2012). Kecenderungan ini merupakan signal tingginya permintaan akan agrowisata dan sekaligus membuka peluang bagi pengembangan produk-produk agribisnis, baik 
dalam bentuk kawasan ataupun produk pertanian yang memiliki daya tarik spesifik. Hamparan areal pertanaman yang luas seperti areal perkebunan dan hortikultura, disamping menyajikan pemandangan dan udara segar, juga merupakan media pendidikan bagi masyarakat dalam dimensi yang sangat luas, mulai dari pendidikan tentang usaha di bidang perkebunan atau hortikultura tersebut, sampai pendidikan tentang keharmonisan dan kelestarian alam.

Tirtawinata, Moh. Reza dan Lisdiana Fachruddin (1999) menyatakan ada lima manfaat agrowisata yaitu (a) meningkatkan konservasi lingkungan, (b) meningkatkan nilai estetika dan keindahan alam, (c) memberi nilai rekreasi, (d) meningkatkan kegiatan ilmiah dan pengembangan ilmu pengetahuan, dan (e) mendapatkan keuntungan ekonomi.

Dalam Peraturan Daerah Kabupaten Gianyar Nomor 16 Tahun 2012 tentang RTRW, agrowisata didefinisikan sebagai kegiatan perjalanan yang dilakukan oleh seseorang atau sekelompok orang dengan mengunjungi kawasan pertanian untuk tujuan rekreasi, pengembangan pribadi, atau mempelajari keunikan daya tarik wisata yang dikunjungi dalam jangka waktu sementara.

Agrowisata dalam artikel ini didefinisikan sebagai sebuah bentuk kegiatan pariwisata yang memanfaatkan potensi alam, pertanian (agro), budaya, dan aktivitas masyarakat pedesaan sebagai daya tarik wisata, dengan tujuan untuk memperluas pengetahuan, pengalaman, area rekreasi, dan hubungan usaha agribisnis pedesaan. Agrowisata dikembangkan berdasarkan konsep pengembangan wilayah, melalui pemanfaatan potensi alam, pertanian, budaya, dan aktivitas masyarakat lokal dan mengacu pada prinsip-prinsip pembangunan pariwisata berkelanjutan.

Agrowisata berbasis masyarakat di Desa Kerta diharapkan dapat memacu pertumbuhan dan perkembangan usaha-usaha agribisnis, mendorong peningkatan kuantitas dan kualitas sumber daya manusia, penguatan kelembagaan pertanian, sosial-budaya, dan ekonomi, membuka kesempatan berusaha seluas-luasnya bagi masyarakat setempat dan sekitarnya. Selain itu, pengembangan Agrowisata Desa Kerta, juga diharapkan mampu menjaga kelestarian alam, kekayaan sumberdaya alam hayati (pertanian), budaya, dan aktivitas masyarakat lokal.

\section{Kemandirian Ekonomi}

Konsep kemandirian ekonomi nasional berpijak pada NAWACITA Presiden Republik Indonesia, yaitu mewujudkan kemandirian ekonomi dengan menggerakan sektor-sektor strategis ekonomi domestik. Pertanian dan pariwisata merupakan sektor strategis yang mampu menopang kehidupan sekaligus sebagai penggerak ekonomi nasional yang mengakar dan menjadi kultur pada masyarakat Indonesia (Kamino, 2015). Lebih lanjut 
Kamino (2015) menyatakan bahwa sinergi pertanian dan pariwisata yang dikemas sebagai agrowisata telah menjadi daya tarik wisata yang sejajar dengan daya tarik wisata lainnya seperti daya tarik wisata alam, wisata budaya, wisata bahari dan lainnya.

Manfaat ekonomi merupakan aspek penting dalam pengembangan agrowisata, selain aspek kelestarian alam, sosial dan budaya. Aspek ekonomi dapat dilihat dari nilai tambah yang diciptakan dari pengelolaan agrowisata tersebut. Untuk dapat meningkatkan nilai tambah sektor pertanian, maka pengelolaannya harus disinergikan dengan sektor-sektor lainya. Selain itu, juga harus diintegrasikan dengan daya dukung wilayah seperti keragaman hayati, demografis dan letak geografis, agar menjadi kekuatan faktor-faktor internal dan perekonomian wilayah.

Mendayagunakan keragamanan sumberdaya alam hayati sebagai sumber pendapatan merupakan manfaat langsung yang diperoleh dari kegiatan agrowisata. Sedangkan manfaat tidak langsung dari kegiatan agrowisata tersebut adalah mendorong tumbuh-kembangnya unit-unit usaha agribisnis dalam berbagai tingkatan skala usaha serta mendorong tumbuh-kembangnya kelembagaan ekonomi petani dan jaringan usahanya.

Pengembangan Agrowisata Desa Kerta yang didasarkan pada prinsip-prinsip pembangunan pariwisata berkelanjutan, akan mendorong pertumbuhan ekonomi masyarakat secara merata dan berkesinambungan. Selain memberi manfaat ekonomi bagi masyarakat lokal dan sekitarnya, agrowisata juga akan memberi manfaat lingkungan, keindahan dan pengetahuan. Keuntungan ekonomi yang diperoleh secara langsung berdampak pada meningkatnya pendapatan masyarakat dan selanjutnya berdampak pada meningkatnya tarap hidup dan kesejahteraan masyarakat setempat (petani).

\section{Kelestarian Alam dan Budaya}

Berdasarkantipologi,kapabilitasdanfungsiekologislahan,pengembangan agrowisata secara langsung dapat mempengaruhi kelestarian alam, budaya dan pendapatan petani. Kegiatan ini akan menciptakan lapangan pekerjaan dan menyerap tenaga kerja. Secara tidak langsung kegiatan agrowisata akan berdampak pada meningkatkan motivasi petani untuk melestarikan alam/ lahan pertanian, teknologi lokal dan budaya, utamanya budaya agraris dan budaya tradisi.

World Tourism Organization (WTO) yang dikutif Kamino (2015) menggariskan kebijakan pengembangan pariwisata berkelanjutan (sustainable tourism) pada tiga hal, yaitu berkelanjutan alam, sosial, budaya, dan ekonomi. Konsep ini sangat sesuai dengan pembangunan pariwisata di Indonesia, yaitu dengan mensinergikan sektor pertanian dan pariwisata, yang dikemas dalam bentuk agrowisata. 
Sinergitas pertanian dan pariwisata yang dikemas sebagai agrowisata merupakan model pariwisata yang dapat diterima oleh masyarakat luas. Hal ini sejalan dengan meningkatnya kesadaran masyarakat akan nilai-nilai hubungan manusia dengan lingkungan alam maupun nilai-nilai budaya yang ada. Selain itu, kegiatan agrowisata juga dapat mengarahkan pembangunan wilayah pada trend yang mengedepankan pelestarian alam (back to nature). Aspek pelestarian budaya dapat ditunjukkan melalui atraksi budaya, baik budaya tradisional maupun budaya agraris. Adanya atraksi budaya dalam kegiatan agrowisata akan mendorong adanya pembinaan dan pelestarian budaya secara berkesinambungan.

Kebijakan Kementerian Pertanian adalah menyediakan pasokan pangan bagi setiap warga negara, meningkatkan daya saing dan nilai tambah dengan tetap memperhatikan kelestarian sumber daya alam dan lingkungan hidup serta kearifan lokal. Sejalan dengan hal tersebut, sektor pertanian harus disinergikan dengan sektor pariwisata dan sektor lainnya. Agrowisata merupakan model sinergitas sektor pertanian dan pariwisata yang mengedepankan kelestarian alam, lingkungan dan budaya. Menurut Kasimo (2015) Agrowisata adalah wisata paling mungkin dikembangkan karena selaras dengan prinsip Ajeg Bali, yaitu keberlanjutan pembangunan yang didasarkan pada sumberdaya alam, sosial-budaya dan manfaat ekonomi yang diperoleh masyarakat lokal. Konsep ini sejalan dengan konsep pengembangan Agrowisata Desa Kerta yang berpegang pada prinsip-prinsip pembangunan pariwisata berkelanjutan.

\section{Potensi Desa sebagai Daya Tarik Agrowisata}

Potensi desa sebagai daya tarik agrowisata dapat dibedakan menjadi dua, yaitu potensi desa yang sudah berkembang menjadi daya tarik agrowisata dan potensi desa yang dapat/potensial dikembangkan menjadi daya tarik agrowisata.

\subsection{Potensi Desa yang Sudah Berkembang menjadi Daya Tarik Agrowisata}

Potensi desa yang sudah berkembang menjadi daya tarik agrowisata, dikategorikan menjadi empat, yaitu potensi alam, potensi pertanian, potensi budaya, dan potensi aktivitas.

\section{a. Potensi alam.}

Potensi alam yang sudah berkembang menjadi daya tarik agrowisata adalah panorama alam. Panorama alam di tempat ini keberadaannya cukup banyak, yaitu panorama sawah, gunung, lembah, perkebunan jeruk, hutan bambu dan kebun bunga potong tropika, seperti terlihat pada Foto 1.

\section{b. Potensi Pertanian}

Potensi pertanian (agro) yang sudah berkembang menjadi daya tarik 

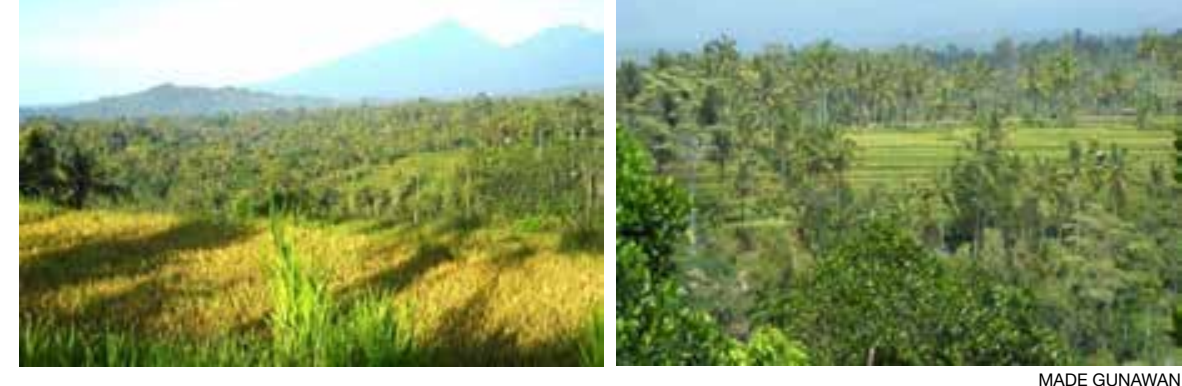

Foto 1. Panorama Alam

agrowisata adalah bunga potong tropika. Bunga potong yang pertama kali dikembangkan di Desa Kerta adalah bunga potong tropika jenis Heliconia (pisang-pisangan). Pengembangan bunga potong jenis ini, dimulai sejak tahun 2003 oleh kelompok tani Sekar Bumi dan mengalami perkembangan luas areal penanaman, jumlah populasi dan varietas. Bunga potong tropika (pisang hias) menjadi salah satu komoditi unggulan di tempat ini, karena memiliki beberapa kelebihan, diantaranya mudah dibudidayakan/ dikembangkan, pertumbuhan yang relatif cepat, memiliki jumlah anakan yang cukup banyak, memiliki nilai ekonomi yang cukup tinggi, dapat dimanfaatkan sebagai pakan ternak dan tanaman konservasi. Tanaman bunga potong tropika dapat dilihat pada Foto 2 .

\section{c. Potensi budaya}

Desa Kerta memiliki potensi budaya masa lalu (cultural heritage) dan potensi budaya yang masih hidup/berlanjut (living cultural) sampai sekarang. Potensi budaya yang sudah berkembang menjadi daya tarik wisata adalah Sarkopag Marga Tengah dan jembatan Kuning. Sarkofagus merupakan tempat untuk menyimpan jenazah pada zaman dahulu yang terbuat dari batu. Sarkofagus pada umumnya diukir dan dihias. Peninggalan sarkofagus (makam jenazah) yang terdapat di Desa Kerta, berada di areal Pura Kawitan Desa Pekraman Margatengah. Situs ini dibongkar pada tahun 1975. Pada saat pembongkaran peti batu tersebut ditemukan kerangka tulang dan perhiasan berupa perunggu dan emas. Menurut sejarah kerangka tulang tersebut merupakan kerangka tulang dari pemimpin terdahulu, yaitu Ida Ratu Gede Dukuh Sakti. Hal ini dibuktikan dari banyaknya perhiasan dan senjata, serta terdapatnya selempang pada kerangka tersebut, menunjukaan bahwa yang dimakamkan adalah seorang dari kaum bangsawan.

Jembatan Kuning adalah jembatan yang menguhungkan Banjar Penyabangan dan Banjar Pilan. Jembatan ini cukup terkenal dan banyak dikunjungi kalangan anak muda. Jembatan ini memiliki panjang 64 meter dan lebarnya satu meter dan dibawahnya terdapat sungai. Ketinggian jembatan dari sungai mencapai adalah 70 meter. Pada awal dibangunnya, jembatan ini berwarna merah, namun seiring berjalannya waktu, kondsi jembatan menjadi usang dan berkarat. Pada tahun 2013, Pemerintah Kabupaten Gianyar merehabilitasi jembatan ini dan merubbah warnanya 

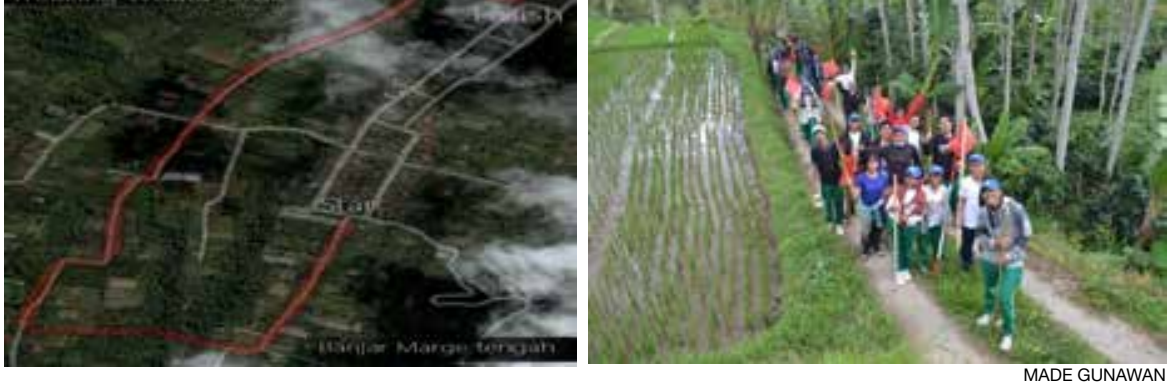

Foto 5. Rute dan Aktivitas Trekking
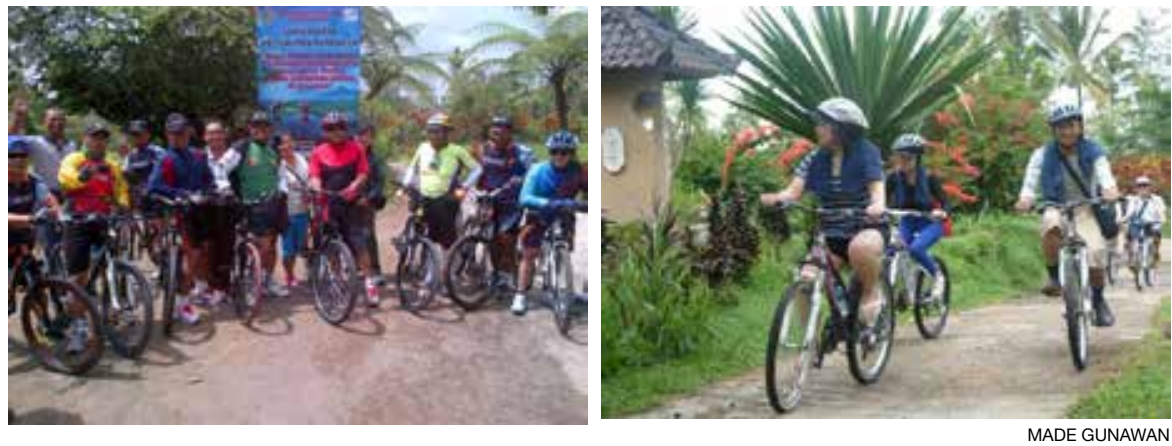

Foto 6. Aktivitas Cycling

trekking yang ada di Desa Kerta Kecamatan Payangan Kabupaten Gianyar, dapat dilihat pada Foto 5 .

Rute trekking yang terdapat di tempat ini, dikatagoraikan menjadi tiga, yaitu jarak pendek, jarak menengah dan jarak jauh. Jarak pendek, dapat ditempuh dengan waktu satu jam, jarak menengah, dapat ditempuh dengan waktu dua jam, dan rute jarak jauh membutuhkan waktu lebih panjang yaitu tiga sampai lima jam. Selama perjalanan, wisatawan disuguhkan pemandangan alam yang eksotik.

Potensi alam dan pertanian yang cukup besar, dengan infrastruktur jalan (aksesibilitas) yang cukup memadai, cocok dikembangkan aktivitas cycling. Aktivitas wisata bersepeda (cycling) di Desa Kerta dapat dilihat Foto 6.

Wisata buggy, ATV dan kano/tubing merupakan wisata petualangan alam. Aktivitas wisata ini cukup menantang bagi wisatawan yang suka berpetualang dan menyukai tantangan. Wisata quad dan tubing merupakan wisata yang cukup diminati oleh wisatawan mancanegara maupun nusantara.

Potensi sumber daya lahan dan sumber daya air, menciptakan banyak peluang usaha dan daya tarik, salah satunya adalah pengembangan budidaya ikan untuk memenuhi kebutuhan konsumsi dan wisata mancing. Aktivitas memancing di kolam ikan Amertha Bhuana Sari, cukup diminati wisatawan lokal.

\subsection{Potensi Desa yang Dapat Berkembang menjadi Daya Tarik Agrowisata}

Potensi desa yang dapat/potensial dikembangkan menjadi daya tarik agrowisata, yakni potensi wisata alam, potensi wisata pertanian, potensi 

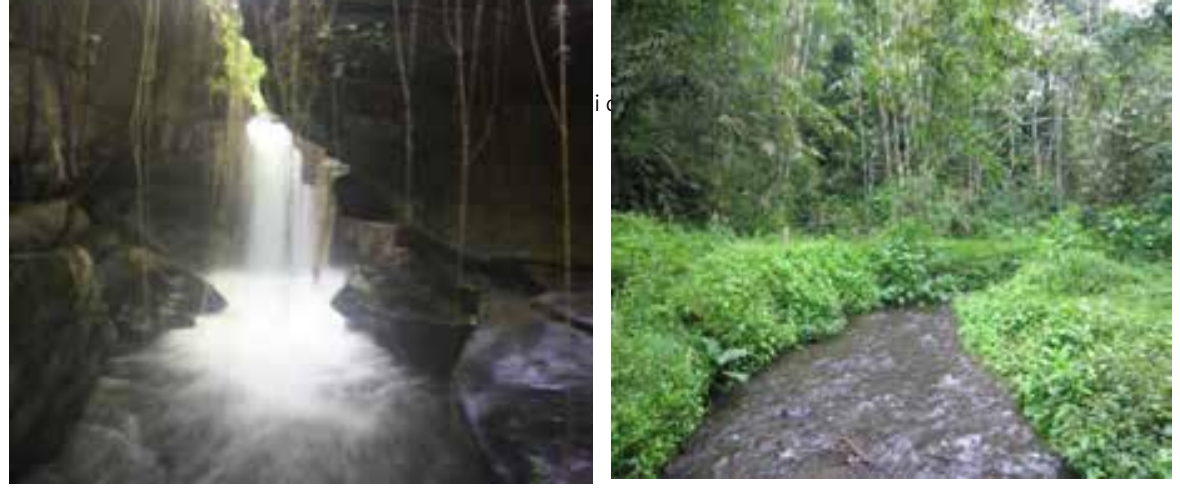

Foto 7. Mata Air dan Sungai

wisata budaya, dan potensi wisata aktivitas.

\section{a. Potensi Alam}

Potensi wisata alam yang dapat/potensial dikembangkan menjadi daya tarik agrowisata adalah mata air dan sungai, air terjun, hutan, serta flora dan fauna. Mata air yang keluar dari celah-celah tembok batu dan sungai yang berkelok-kelok tampak mempesona. Kondisi tersebut cukup potensial menjadi daya tarik wisata di tempat ini, seperti terlihat pada Foto 7.

Pemerintah Kabupaten Gianyar, telah menetapkan kebijakan strategis untuk menjadikan hutan ini sebagai Kebun Raya Bertema (Kebun Raya Tematik). Kebijakan ini merupakan langkah penting dan sangat strategis bagi pengembangan Agrowisata Desa Kerta sebagai pariwisata berkelanjutan di Kawasan Agropolitan Payangan. Tempat ini dapat menjadi media atau tempat pembelajaran dan pemberdayaan masyarakat lokal dan masyarakat sekitarnya dalam mengelola dan memanfaatkan sumberdaya hutan sebagai sumber pendapatan, pendidikan dan pelestarian sumberdaya alam hayati.

Di samping itu, Kebun Raya Tematik ini, akan menjadi daya tarik agrowisata yang langka dan unik di Kawasan Agroplitan Payangan dan di Kawasan Agrowisata Gianyar Utara, sebab keberadaan kebun raya ini, satu-satunya di wilayah Kabupaten Gianyar. Di tempat ini, wisatawan akan memperoleh tambahan pengetahuan dan pengalaman tentang flora, fauna, tradisi dan pola kehidupan masyarakat lokal Bali Aga. Selain itu, wisatawan juga dapat mengunjungi dan menikmati daya tarik wisata lainnya wisata jembatan Kuning, suasana hutan Pucak Sari, goa Raksasa, dan goa gerombolan.

Desa Kerta memiliki tingkat keragaman flora dan fauna yang cukup tinggi. Tumbuh berbagai jenis flora baik di areal kawasan maupun daerah aliran sungai dan perlindungan jurang. Selain itu, di wilayah ini juga terdapat beberapa jenis satwa seperti kidang, monyet atau kera, menjangan, berbagai jenis burung dan hewan melata lainnya.

\section{b. Potensi Pertanian}

Potensi pertanian yang dapat/potensial dikembangkan sebagai produk/ daya tarik Agrowisata Desa Kerta, adalah persawahan (subak), perkebunan jeruk, kebun sayuran, dan perkebunan kopi.

Pemandangan alam berupa sawah dengan aktivitas krama subaknya bagi 
kebanyakan wisatawan merupakan hal yang unik, yang sulit ditemukan di negara atau daerahnya sendiri, sehingga kunjungan wisatawan ke pulau dewata dimanfaatkan untuk melihat keberadaan sawah dan aktivitas krama subaknya.

Pemandangan atau panorama sawah yang eksotik, telah menciptakan kesan dan pengalaman unik bagi para wisatawan yang berkunjung ke Pulau Dewata, sehingga tidak jarang para pelaku ataupun pengusaha pariwisata menjadikan sawah sebagai salah satu daya tarik dalam paket wisata atau paket tournya. Aktivitas membajak sawah dan penanaman padi oleh krama subak, dilakukan dengan menggunakan sistem jajar logowo tipe 2:1, di mana sistem ini diyakini telah memberikan peningkatan produksi padi yang cukup signifikan, dibandingkan sistem penanaman sebelumnya. Di samping sebagai penyedia kebutuhan pangan, keberadaan Subak telah mengundang perhatian banyak orang, utamanya wisatawan, baik nusantara maupun manca negara, karena subak hanya dapat dilihat/ditemukan di Bali. Subak dengan terasseringnya yang berundak, telah menciptakan panorama yang indah dan memukau banyak orang, sehingga menjadi daya tarik yang sangat kuat bagi wisatawan atau siapa saja yang menyaksikan keindahan panorama dan aktivitasnya yang unik dan langka

Perkebunan jeruk memiliki potensi besar untuk dikembangkan menjadi daya tarik agrowisata. Selain tampak indah dan tertata rapi, di areal perkebunan jeruk, juga dapat dikembangkan berbagai aktivitas wisata, antara lain aktivitas membuat bibit, menanam, panen/petik jeruk maupun aktivitas pengolahan buah jeruk menjadi bentuk lain seperti camilan (snack) yang dapat dikemas menjadi lebih menarik, dengan daya simpan lebih lama. Aktivitas semacam ini, dapat menjadi atraksi wisata menarik bagi wisatawan yang berkunjung ke wilayah ini.

Komoditi sayuran yang berkembang di Desa Kerta telah memberi andil besar bagi perekonomian masyarakat di daerah ini. Hal ini dapat dilihat dari intensitas kegiatan budidaya sayuran yang sangat tinggi dan dilakukan merata oleh masyarakat petani di seluruh wilayah Desa Kerta.

Perkebunan kopi yang ada di Desa Kerta merupakan perkebunan milik rakyat dan perkebunan milik Pemerintah Provinsi Bali yang dikelola oleh Dinas Perkebunan Provinsi Bali. Di areal ini dikembangkan atau dibudidayakan berbagai jenis kopi dengan varietas unggul. Di areal perkebunan ini, dilakukan berbagai aktivitas, mulai dari pembibitan, pembudidayaan, pemanenan dengan sistim petik merah, penanganan pasca panen dan pemasaran hasil.

Hamparan kebun kopi yang luas menciptakan panorama yang indah dan menarik, terutama saat tanaman kopi berbunga dan berbuah, sehingga menciptakan daya tarik bagi yang menyaksikannya. Memetik buah kopi adalah salah satu tahapan dalam budidaya tanaman kopi yang dapat 
dilakukan dengan mudah oleh siapa saja tanpa memerlukan keterampilan khusus. Aktivitas memetik kopi, dapat dijadikan atraksi wisata yang menarik bagi wisatawan.

\section{c. Potensi Budaya}

Potensi budaya yang dapat dikembangkan sebagai daya tarik agrowisata, yaitu tradisi Bali Aga (Ulu Apad) dan situs goa. Di Desa Kerta terdapat empat dari delapan desa adat/pekraman, yang masih menganut tradisi Bali Aga. Pada desa-desa ini, tidak dikenal dengan adanya sistem kasta, pendeta tertinggi tidak melakukan upacara pediksan, tetapi kepemimpinannya menganut pola kembar atau kolektif. Pola kembar bermakna bahwa dalam kepemimpinan selalu ada dua orang, yaitu kanan dan kiri (tengen/kanan dan kiwe/kiri).

Dalam tradisi Bali Aga, pada umumnya dipimpin oleh Kebayan (tengen/ kanan) dan Kebau (tengen/kanan). Kebayan Tengen (kanan), merupakan pemimpin utama dalam sistim kepemimpinan Bali Aga. Kepemimpinan pada masyarakat Bali Aga, memiliki keunikan tersendiri, yaitu kepemimpinannya memakai sistem Ulu Apad. "Ulu" berarti Kepala dan "Pucuk" dan "Apad" berarti Tingkatan. Jadi Ulu Apad berarti kepemimpinan yang di mulai dari tingkatan bawah sampai ke puncak, berdasarkan undagan atau tingkatan yang harus dilewati. Sistem ini mengangkat siapapun menjadi pemimpin tanpa melihat latar belakang pendidikan atau pekerjaan berdasarkan urutanurutan masuk menjadi Krama Desa Adat. Sistem ini menggunakan hirarkis, seperti silsilah keluarga.

Di Banjar Pilan terdapat cerita rakyat mengenai Goa Raksasa. Goa tersebut telah diceritakan secara turun-temurun oleh masyarakat Banjar Pilan. Pada zaman dahulu, ketika masyarakat melaksanakan upacara (yadnya) di Pura Pucak Sari, terdapat tari-tarian Rejang sebagai pengiring upacara tersebut. Penari Rejang yang jumlahnya tidak tetap tersebut dengan lemah gemulai menggerakan tubuhnya. Tari Rejang ditarikan sebagai bentuk persembahaan kepada para dewa, namun keanehan muncul, salah satu kitut penari yaitu penari yang berada pada barisan paling belakang menghilang tanpa jejak saat upacara di pura tersebut. Hal tersebut juga terjadi saat dilaksanakan upacara yadnya di Pura Puseh.

Sebelum penari Rejang tersebut menghilang, selalu disertai kabut asap, sehingga menjadi misteri hilangnya kitut penari Rejang atau penari yang berada pada barisan paling belakang. Masyarakat yang resah dengan hilangnya para penari berinisiatif untuk mengungkap keanehan tersebut, sehingga pada saat dilangsungkan upacara di Pura Pucak Sari berikutnya, penari Rejang pada barisan paling belakang diikati dengan sekantong mincid (beras hancur) sebagai penanda jejak dan diberi lubang kecil pada kantong tersebut.

Akhirnya kebenaran itu terungkap, bahwa kantong mincid yang sudah 
diberi lubang kecil tersebut menunjukkan jejak hilangnya penari Rejang saat upacara di Pura Pucak Sari tersebut. Setelah ceceran mincid diikuti, sampailah masyarakat Pilan di sebuah goa, yang diketahui ternyata goa tersebut dihuni oleh raksasa yang selama ini telah menculik para penari Rejang sebagai santapannya. Karena merasa terancam dengan keberadaan raksasa di goa itu, kemudian masyarakat mengumpulkan ijuk di mulut goa, setelah ijuk terkumpul masyarakat kemudian membakarnya. Asap dan udara panas yang mengepul masuk ke dalam goa berhasil membunuh raksasa tersebut. Namun, musibah tak berhenti sampai di situ. Saat-saat terakhir sebelum kematiannya raksasa mengutuk masyarakat Banjar Pilan, hingga banyak masyarakat yang meninggal ketika itu. Masyarakat Pilan percaya bahwa adanya anak yang terlahir cacat di tempat ini adalah pengaruh dari kutukan raksasa tersebut. Diperkirakan goa tersebut sudah ada sejak zaman prasejarah. Kini Goa Raksasa tidak dapat dimasuki lebih dalam lagi sejak tertimbun reruntuhan, konstruksinya yang labil menyebabkan goa tersebut tidak aman untuk dimasuki.

Menurut penuturan beberapa warga bahwa goa-goa tersebut dulunya dipakai untuk persembunyian para gerombolan yang suka memalak harta penduduk yang ada di wilayah itu. Warga dipaksa untuk membawakan makanan ke tempat persembunyiannya dan mereka juga memaksa mengambil barang, ternak, hasil kebun atau harta penduduk untuk memenuhi kebutuhan mereka dipersembunyian. Mereka juga tidak segansegan menyiksa bahkan membunuh penduduk, bila dianggap membangkang atau tidak mau menyerahkan barang, ternak, hasil kebun atau hartanya kepada mereka.

\section{d. Potensi aktivitas}

Potensi aktivitas masyarakat yang dapat/potensial menjadi daya tarik agrowisata, yakni aktivitas pertanian, memetik jeruk, membuat kerajinan bambu dan ukiran kayu, memetik dan mengolah kopi. Aktivitas pertanian cukup banyak dapat dijadikan atraksi wisata, diantaranya membajak, menanam atau memanen padi. Membajak sawah adalah kegiatan rutin petani lahan basah, yang dilakukan setelah panen padi. Kegiatan ini pada umumnya memanfaatkan sepasang sapi dan alat-alat tradisonal seperti tenggala, singkal, pengigi, samed, camok, lampit, pecut dan lain-lain.

Di Desa Kerta aktivtas membajak secara tradisional masih cukup banyak dijumpai dan sering menjadi sasaran lensa atau obyek perhatian wisatawan yang singgah ke wilayah ini. Membajak sawah merupakan aktivitas masyarakat (petani) yang dapat dikemas menadi atraksi wisata menarik. Aktivitas memanen padi, juga dapat menjadi atraksi wisata yang unik bagi wisatawan. Aktivitas membajak, menanam dan memanen perlu dibuat pengaturan pada luasan tertentu, karena adanya tidak setiap hari. Aktivitas membajak sawah dan memanen padi adalah aktivitas yang sangat 


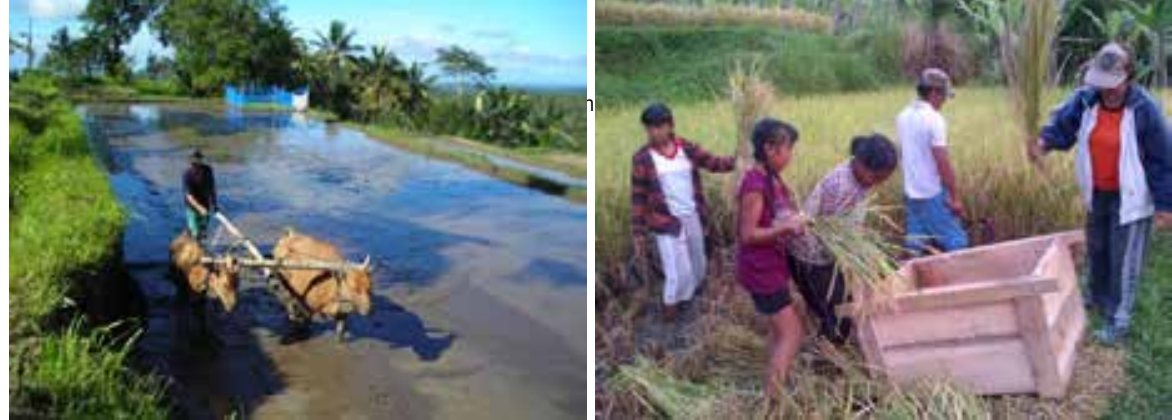

Foto 8. Aktivitas membajak sawah dan memanen padi.

mengasyikkan, seperti tampak pada Foto 8.

Aktivitas memetik jeruk sambil menikmati cita rasa buah jeruk juga merupakan aktivitas yang sangat menyenangkan. Aktivitas semacam ini, dapat menjadi atraksi wisata yang cukup menarik bagi wisatawan yang berkunjung ke tempat ini. Selain itu aktivitas pembuatan kerajian bambu dan ukir kayu ini, dapat/potensial menjadi daya tarik wisata. Hasil kerajinan bambu cukup diminati konsumen/wisatawan, karena jenis dan desainnya yang cukup beragam serta banyak dijadikan sebagai cinderamata. Ukiran kayu kebanyakan dimanfaatkan sebagai ornamen bangunan, baik bangunan tempat suci, rumah maupun bangunan-bangunan lainnya. Di samping itu. Di tempat ini juga terdapat perkebunan kopi miliki masyarakat lokal dan perkebunan kopi miliki Pemerintah Provinsi Bali. Aktivitas memetik dan mengolah kopi dapat/potensial menjadi atraksi wisata bagi wisatawan.

\section{Faktor-Faktor yang Mempengaruhi Agrowisata Berbasis Masyarakat}

Faktor-faktor yang mempengaruhi pengembangan agrowisata berbasis masyarakat di Desa Kerta adalah factor internal dan factor eksternal.

\subsection{Faktor Internal}

Faktor internal yang mempengaruhi pengembangan agrowisata berbasis masyarakat di Desa Kerta dibedakan menjadi dua, yaitu kekuatan dan kelemahan. Faktor internal berupa kekuatan terdiri atas:

(1) kebijakan Pemerintah Kabupaten Gianyar menjadikan Desa Kerta sebagai Desa Pusat Pertumbuhan di Kawasan Agropolitan Payangan Kabupaten Gianyar dan Pusat Pengembangan Agrowisata Gianyar Utara,

(2) panorama alam yang indah,

(3) lahan pertanian yang luas dan subur,

(4) keragaman komoditas pertanian yang tinggi,

(5) keberadaan hutan yang luas dan lestari, mata air yang berlimpah dengan sungai yang mengalir sepanjang tahun,

(6) subak dengan tradisinya yang masih lestari,

(7)kerajinan bambu dan ukiran kayu yang berkembang baik,

(8)tradisi Bali Aga dan adat istiadat yang masih kental/kuat,

(9) terpeliharanya situs purbakala;

(10) adanya Komite Pariwisata (BPDW); 
(11) adanya aktivitas wisata yang sudah berkembang baik,

(12) sikap dan prilaku masyarakat yang mendukung pengembangan agrowisata,

(13) infrastruktur jalan (aksesibilitas) yang memadai, dan

(14) letak geografis yang strategis.

Hasil analisis faktor internal menunjukkan bahwa panorama alam yang indah memiliki nilai rata-rata (rating) tertinggi, yaitu 3,900. Ini berarti, panorama alam yang indah merupakan faktor sangat penting dan paling berpengaruh dalam pengembangan agrowisata berbasis masyarakat di Desa Kerta. Selain itu, hasil studi tiga lembaga/organisasi dunia, yaitu PATA yang melakukan studi pada tahun 1984, American Express tahun 1977 di Hongkong dan Dirjen Pariwisata tahun 1993, juga menyatakan bahwa pemandangan alam yang indah merupakan sifat yang paling penting sekaligus faktor paling berpengaruh dalam sebuah destinasi wisata.

Keberadaan hutan yang luas dan lestari, mata air yang berlimpah dengan sungai yang mengalir sepanjang tahun serta subak dengan tradisinya yang masih lestari, kebijakan Pemerintah Kabupaten Gianyar menjadikan Desa Kerta sebagai Pusat Pengembangan Agrowisata Gianyar Utara, lahan pertanian yang luas dan subur, keragaman komoditas pertanian yang tinggi, letak geografis yang strategis, serta aktivitas wisata yang sudah berkembang baik, adalah faktor internal yang menjadi kekuatan paling dominan dalam pengembangan Agrowisata Desa Kerta.

Faktor internal yang menjadi kelemahan terdiri dari

(1) sumber daya manusia yang belum memadai,

(2) terbatasnya wawasan masyarakat tentang agrowisata,

(3) minimnya fasilitas akomodasi,

(4) terbatasnya fasilitas restoran/rumah makan yang tersedia,

(5) minimnya informasi pariwisata,

(6) minimnya fasilitas umum penunjang pariwisata, dan

(7) belum tertatanya toko cinderamata.

\subsection{Faktor Eksternal}

Faktor eksternal yang mempengaruhi pengembangan agrowisata berbasis masyarakat di Desa Kerta, juga dibedakan menjadi dua yaitu faktor eksternal berupa peluang dan factor eksternal berupa ancaman. Faktor eksternal yang berupa peluang adalah (1) situasi sosial politik dalam negeri Indonesia yang kondusif, (2) situasi perekonomian Indonesia (iklim investasi) yang semakin membaik, (3) kondisi alam Bali yang nyaman dan stabil, (4) situasi keamanan Bali yang kondusif, (5) meningkatnya minat pengusaha lokal (Bali) untuk berinvestasi dan menjalin kerjasama usaha dengan masyarakat lokal, (6) kebijakan Pemda Gianyar menjadikan Gianyar Utara sebagai Kawasan Pengembangan Agrowisata, (7) adanya keterpaduan unsur-unsur 
dalam pengembangan agrowisata, (8) meningkatnya alokasi anggaran dari Pemerintah dan Pemerintah Daerah untuk pengembangan agrowisata, (9) meningkatnya kerjasama pemerintah, swasta dan masyarakat., dan (10) meningkatnya minat wisatawan terhadap daya tarik agrowisata.

Faktor eksternal yang menjadi ancaman dalam pengembangan agrowisata di Desa Kerta adalah (1) kondisi ekonomi global yang tidak stabil, (2) perubahan iklim (ekstrem), (3) belum adanya Perda tentang penatausahaan daya tarik agrowisata, (4) keberadaan dan berkembangnya aktivitas agrowisata di tempat lain, di luar Desa Kerta, (5) tingginya penggunaan pestisida di sektor pertanian.

\section{Strategi dan Program Pengembangan Agrowisata Berbasis Masyarakat}

Strategi dan program yang dapat diterapkan dalam pengembangan Agrowisata Desa Kerta sebagai pariwisata berkelanjutan di Kawasan Agropolitan Payangan Kabupaten Gianyar, adalah 1) strategi SO, diterapkan strategi mengembangkan produk agrowisata berkualitas dengan delapan program, strategi mengembangkan paket agrowisata dengan delapan program, strategi meningkatkan promosi dengan teknologi informasi melalui program online dan offline, dan strategi meningkatkan kapasitas pengelola dan kelembagaan desa dengan dua program; 2) Strategi ST, diterapkan strategi mengembangkan pasar dalam negeri/nusantara dengan tiga program dan strategi menetapkan peraturan tentang penatausahaan agrowisata dengan tiga program; 3) Strategi WO, diterapkan startegi meningkatkan SDM dan wawasan masyarakat dengan tujuh program dan strategi meningkatkan fasilitas penunjang agrowisata dengan empat program; dan 4) Strategi WT, diterapkan strategi mengembangkan program kampung iklim dengan lima program dan strategi meningkatkan promosi pertanian organik dengan tiga program.

\section{Simpulan}

Berdasarkan pembahasan dapat disimpulkan beberapa hal berikut. Pertama, potensi desa yang sudah berkembang menjadi produk Agrowisata Desa Kerta, yaitu a) potensi alam adalah wisata menikmati panorama alam, b) potensi pertanian adalah menikmati suasana persawahan dan wisata agro bunga potong tropika, c) potensi budaya yakni wisata mengunjungi sarkofagus Marga Tengah dan wisata jembatan Kuning, dan d) potensi aktivitas, yakni aktivitas merangkai bunga, wisata trekking, wisata cycling, atraksi flying fox, wisata buggy, ATV/quad, kano/tubing, dan wisata mancing. Potensi Desa yang dapat/potensial dikembangkan menjadi produk/daya tarik Agrowisata Desa Kerta di Kawasan Agropolitan Payangan Kabupaten Gianyar, yaitu a) potensi alam, antara lain sungai, air terjun, hutan, flora dan fauna, b) potensi agro antara lain perkebunan jeruk, sayuran, dan kopi, c) potensi budaya yaitu 
tradisi Bali Aga (Ulu Apad) dan situs Goa, dan d) potensi aktivitas, antara lain aktivitas pertanian, wisata petik jeruk, membuat kerajinan bambu dan ukiran kayu, wisata petik dan olah kopi.

Kedua, faktor internal dan eksternal yang mempengaruhi pengembangan Agrowisata Desa Kerta sebagai pariwisata berkelanjutan di Kawasan Agropolitan Payangan Kabupaten Gianyar, yaitu empat belas faktor internal berupa kekuatan dan tujuh faktor internal berupa kelemahan. Sepuluh faktor eksternal berupa peluang dan lima faktor eksternal berupa ancaman.

Ketiga, Strategi dan program yang harus diterapkan dalam pengembangan Agrowisata Desa Kerta sebagai pariwisata berkelanjutan di Kawasan Agropolitan Payangan Kabupaten Gianyar, adalah grow and build, yaitu pengembangan produk, pengembangan pasar, dan penetrasi pasar. Strategi tersebut dikategorikan menjadi empat strategi, yaitu: (1) Strategi SO, diterapkan strategi mengembangkan produk agrowisata berkualitas dengan delapan program, startegi mengembangkan paket agrowisata dengan delapan program, startegi meningkatkan promosi dengan teknologi informasi melalui program online dan offline, dan strategi meningkatkan kapasitas pengelola dan kelembagaan desa dengan dua program, (2) Strategi ST, diterapkan strategi mengembangkan pasar dalam negeri dengan tiga program dan strategi menetapkan peraturan tentang penatausahaan agrowisata dengan tiga program; (3) Strategi WO, diterapkan strategi meningkatkan SDM dan wawasan masyarakat dengan tujuh program dan strategi meningkatkan fasilitas penunjang agrowisata dengan empat program.; (4) Strategi WT, strategi mengembangkan program kampung iklim dengan lima program dan strategi meningkatkan promosi pertanian organic dengan tiga program.

\section{Saran}

Dari hasil pembahasan yang dilakukan, dapat disarankan beberapa hal terkait pengembangan Agrowisata Desa Kerta sebagai pariwisata berkelanjutan di Kawasan Agropolitan Payangan Kabupaten Gianyar, yaitu sebagai berikut. Pertama, perlu adanya pendampingan secara berkesinambungan dari Pemerintah Daerah, pakar pariwisata (agrowisata), pakar lingkungan, dan praktisi dalam pengembangan Agrowisata Desa Kerta.

Kedua, perlu adanya langkah-langkah untuk mengantisipasi ancaman faktor-faktor eksternal, di antaranya a) membangun pasar lokal (penetrasi pasar dalam negeri/nusantara/daerah), b) mengurangi aktivitas yang dapat mengganggu atau merusak destinasi dan komonen-komponennya, c) kepada Pemerintah Daerah diharapkan dapat menetapkan Peraturan Daerah, tentang penatausahaan potensi dan daya tarik agrowisata, d) menciptakan produk dan paket agrowisata yang berkualitas dan unik, yang memiliki daya saing global; e) Pemerintah Daerah, masyarakat, dan swasta harus berkomitmen untuk membangun pertanian organik. 


\section{Ucapan Terima Kasih}

Terima kasih yang sebesar-besarnya penulis ucapkan kepada Ketua Program Studi Magister Kajian Pariwisata, Prof. Dr. I Nyoman Darma Putra, M.Litt., atas kesempatan, fasilitas dan bantuan yang diberikan selama studi. Pembimbing I, Prof. Made Sudiana Mahendra, MApp Sc, Ph.D dan Pembimbing II, dan Dr. Dewa Putu Oka Prasiasa, A.Par., MM., anggota penguji Prof. Dr. Wayan Budiarsa, MA. dan Prof. Dr. I Gde Semadi Astra, atas bimbingan, saran dan masukannya. Terima kasih yang sebesar-besarnya kepada Bupati Gianyar, Bapak Anak Agung Gede Agung Barata, S.H., atas ijin dan restunya. Terima kasih kepada Kepala Bappeda Kabupaten Gianyar, Ir. IGN Wisnu Wijaya, M.Si., Kepala BPMD Kabupaten Gianyar, Ir. I Wayan Watha, MM., Kepala Disparda Kabupaten Gianyar, AA. Ari Brahmantia, S.E., dan Kepala Distanhubun Kabupaten Gianyar, Ibu Ir. IGA Dewi Hariani, M.Sc., atas fasilitas, bantuan, dukungan, sarannya.

\section{Daftar Pustaka}

Goodwin, H. 1998. Sustainable Tourism and Property Elimination. Paper on workshop on Sustainable Tourism and Property. United Kingdom.

Kamino, S.S. 2015. Kebijakan Pemerintah Membangun Sektor Pertanian dalam Perspektif Pariwisata dan Membangun Pariwisata dalam Perspektif Pertanian. Makalah Seminar Nasional. 9 Oktober 2015.

Muljadi, A.J dan Warman, H.A. 2014. Kepariwisataan dan Perjalanan. Jakarta: PT. Raja Grafindo Persada.

Mukeri, M. 2012. Kemandirian Ekonomi Solusi untuk Kemajuan Bangsa. Majalah Ilmiah Universitas Pandanaran. Vol. 10 No. 24. 2012.

Peraturan Daerah Kabupaten Gianyar Nomor 16 Tahun 2012 tentang Tata Ruang Wilayah Kabupaten Gianyar Tahun 2012-2032.

Pranoto, S., Ma'arif, S., Sutjahyo, S.H., dan Siregar, H. 2005. Pengembangan Perdesaan Berkelanjutan melalui Model Pengembangan Agropolitan. Jurnal Manajemen dan Agribisnis. Vol. 3 No. 1 Maret 2005.

Surat Keputusan bersama Menteri Pariwisata, Pos dan Telekomunikasi, dan Menteri Pertanian No. KM.47/PW.DOW/MPPT-89 dan Nomor 204/KPTS/ HK/0504/1989.

Tirtawinata, Moh. Reza dan Lisdiana Fachruddin.1999. Daya Tarik dan Pengelolaan Agrowisata. Jakarta: Penebar Swadaya.

Undang-Undang Republik Indonesia Nomor 10 Tahun 2009 tentang Kepariwisataan. 


\section{Profil Penulis}

I Made Gunawan, SP., M.Par adalah Kepala Desa Kerta Kecamatan Payangan Kabupaten Gianyar, Bali. Ia menyelesaikan Program Strata 1 Pertanian/Jurusan Hama dan Penyakit Tanaman pada tahun 1997 di Universitas Udayana, Program Magister Pariwisata tahun 2016, Universitas Udayana. Tahun 1998-2002 pernah bekerja di Villa Taman Raja Payangan, tahun 2004-2007 pernah bekerja di Program Pengembangan Kecamatan (PPK). Selain sebagai Kepala Desa, ia juga sebagai Pengurus Yayasan Bali Sahaja yang bergerak di bidang pendidikan dan sosial, serta sebagai Ketua Sabha Desa di Desa Pekraman Kerta. 